\title{
Lyn McCredden. The Fiction of Tim Winton: Earthed
} and Sacred

Sydney: Sydney UP, 2016. vii + 158 pp. ISBN: 9-781743-325032. AU\$30

Jean-François Vernay

\section{(2) OpenEdition}

\section{Journals}

Electronic version

URL: https://journals.openedition.org/ces/447

DOI: $10.4000 /$ ces. 447

ISSN: 2534-6695

Publisher

SEPC (Société d'études des pays du Commonwealth)

Printed version

Date of publication: 10 June 2019

Number of pages: 121-122

ISSN: 2270-0633

\section{Electronic reference}

Jean-François Vernay, "Lyn McCredden. The Fiction of Tim Winton: Earthed and Sacred", Commonwealth Essays and Studies [Online], 41.2 | 2019, Online since 05 November 2019, connection on 21 July 2021. URL: http://journals.openedition.org/ces/447 ; DOl: https://doi.org/10.4000/ces.447

\section{(c) $\oplus \Theta \Theta$}

Commonwealth Essays and Studies is licensed under a Licence Creative Commons Attribution - Pas d'Utilisation Commerciale - Pas de Modification 4.0 International. 
The Fiction of Tim Winton: Earthed and Sacred. By Lyn McCredden. Sydney: Sydney UP, 2016. vii + 158 pp. ISBN: 9-781743-325032. AU\$30.

Reviewed by Jean-François VERNAY

Tim Winton has written his way to become the darling of Australian readers who enjoy his rich prose evocative of the south-western landscape which he calls home. He can be regarded as a left-leaning writer who has a close affinity with the people and especially the land which he celebrates in his stories. His coastal narratives invariably vividly depict rural communities functioning in harmony with the beach culture. Winton's focus is domestic, if not personal, fathoming the cultural and psychological impact of the Australian land.

Discounting a few slim study guides on selected novels, The Fiction of Tim Winton: Earthed and Sacred is the third single-authored monograph to appear within the span of two decades, and surely the most comprehensive one in terms of the perspectives explored. The fact that Michael McGirr's Tim Winton: The Writer and his Work (Macmillan Education, 1999) was mostly designed as a high school textbook and that Salhia BenMessahel's more traditional approach in Mind the Country: Tim Winton's Fiction (U of Western Australia P, 2006) focused on a thematic discussion of the novelist's literary output partly accounts for the fact that McCredden's analyses can be considered as offering essentially new insights into an enigmatic writer.

In The Fiction of Tim Winton, Professor Lyn McCredden covers extensively the traditional foci of any classical study in literature (namely language, characterisation, plot, themes, narrative voice, genre, and literariness) rearranged as a series of lively discussions on a variety of engaging topics: the world-making function of Winton's art practice, Judith Butler-inspired gender preoccupations, ontological and psycho-emotional reflections, class identity issues, highbrow and lowbrow artistic ambitions, nationalism, literary reception and considerations about the marketplace.

In a string of thematically arranged essays divided into eight sections (excluding the introduction), McCredden gives an insightful analysis into the fictional works of Tim Winton, a hard-to-classify writer she sees as "a shape-shifter" (1) whose complex profile is not easy to delineate: a gifted wordsmith attuned to vernacular speech; a mediamagnet who keeps a respectable distance from critics; a public intellectual who yet feels more comfortable with working-class culture; and a critically acclaimed writer whose work is not inspiring the same volume of critical response as, say, Peter Carey, Patrick White, or David Malouf. Although Winton has a wide international audience (especially in China and the UK), few of the thirty-odd prizes he has received originated from outside Australia. What is more, though he and Thea Astley are - to the best of my knowledge - the sole writers to have won four times the Miles Franklin Literary Award, Australia's most prestigious fiction prize, this does not seem to have given them greater literary stature than two-time Miles Franklin winners Christopher Koch, Patrick White, Thomas Keneally, Rodney Hall, or Alex Miller. To all intents and purposes, Tim Winton comes across as a protean writer who remains a literary conundrum for academia.

From the sound of her narrative voice, Lyn McCredden feels passionate about her subject-matter, which she has previously tackled on repeated occasions through essays, an anthology of criticism (co-edited with Nat O'Reilly, Tim Winton: Critical Essays, U 
of Western Australia P, 2014), and the odd column. To McCredden's loyal readers, the sacred dimension in the writings of Tim Winton - a Christian at heart - will therefore perhaps be of less interest than her more recent forays into the market-driven forces of the publishing industry discussed in the last section of the book. By trying to assess Winton's fictional narrative impact on readers, McCredden joins the more contemporary debates about the transformative power of fiction, which neuroscience tries to clarify by conducting experiments in a certain number of domains such as identity, personality, beliefs, empathy, psychological processes, brain connectivity and function, to mention a few. But McCredden does not draw on the critical material available in cognitive literary studies and so her discussions on that topic, in the absence of any scientific investigation, remain quite speculative.

Yet, it leads onto another concern that has emerged in the past decades in conjunction with the waning engagement of students in literary studies, that is, the calculus of the value of fiction. "The reasons for this state of affairs [has been] summed up [by Nicholas Jose] as a combination of changing intellectual approaches in the academy, including resistance to nationalist constructions of literature; shorter term, market-driven publishing arrangements in an increasingly competitive and globalised media environment; reduced responsibility for cultural heritage, especially literature, in public policy, and the changing habits of new generations of consumers."1

Just like Thea Astley, Miles Franklin, Helen Garner, Dorothy Hewett, David Ireland, Olga Masters, Frank Moorhouse, or Alexis Wright, Tim Winton is a nationalist writer, and more specifically a regional writer. While Winton does not hesitate to write about sensitive environment-related subjects like some of his other prominent fellow writers concerned with ecology (Oodegeroo Noonuccal, Judith Wright, Xavier Herbert, Patrick White, and Richard Flanagan), no in-depth treatment has been given to his activism in The Fiction of Tim Winton: Earthed and Sacred.

Writing about Tim Winton's fiction inevitably induces comments on Australia. It seems to me that this regional dimension is Winton's quintessential trademark which stands for the core identity of his narratives, something that Australian readers are eagerly looking forward to discovering when grabbing one of his books. Thanks to Lyn McCredden, I would now be more attuned to this aspect. In all the existing scholarship in the field, The Fiction of Tim Winton stands out as a dense and exacting book graced with the ability to unravel the Winton mystery. 